\title{
Uji resistensi bacillus yang diisolasi dari plak gigi terhadap merkuri dan gentamisin
}

\author{
${ }^{1}$ Valentino Rakasiwi \\ ${ }^{2}$ Widdhi Bodhi \\ ${ }^{2}$ Billy J. Kepel
}

\author{
${ }^{1}$ Kandidat Skripsi Fakultas Kedokteran Universitas Sam Ratulangi Manado \\ ${ }^{2}$ Bagian Kimia Fakultas Kedokteran Universitas Sam Ratulangi Manado \\ Email: vrakasiwi13@gmail.com
}

\begin{abstract}
Mercury is an element with atomic number (N) of 80 and has 200,59 relative molecule mass (MR $=200,59$ ). People that are regularly exposed by high mercury, such as due to consuming fish that contains mercury, show cognitive disorders. One of the methods of mercury detoxification is by using mercury-resistant microorganism, such as mercury-resistant bacteria. This should occur if low-level mercury in human body mercury in a relatively long period can make the bacteria adapt and reduce the mercury level, therefore, the bacteria are not dangerous anymore. This study aimed to find out whether the bacillus bacteria were resistant to mercury and gentamycin. Bacillus bacteria were incubated in liquid LB media for 24 hours, The results showed that bacteria's colonies were found at $10 \mathrm{ppm}, 20 \mathrm{ppm}$, and $40 \mathrm{ppm}$, but not in $80 \mathrm{ppm}$. For the resistant test against gentamycin, the resistent zone was $15 \mathrm{~mm}$. Conclusion: Bacillus bacteria were resistent to mercury of $10 \mathrm{ppm}, 20 \mathrm{ppm}$, and $40 \mathrm{ppm}$, but were sensitive to mercury of $80 \mathrm{ppm}$ and gentamycin.
\end{abstract}

Keywords: bacillus, mercury, gentamicin, resistant

\begin{abstract}
Abstrak: Merkuri adalah unsur dengan nomor atom (N) 80 serta massa molekul relatif (MR) 200,59. Individu yang secara kontinu terkena paparan merkuri yang tinggi a. l. oleh konsumsi ikan yang mengandung merkuri menunjukkan kerusakan kognitif. Salah satu usaha untuk detoksifikasi merkuri dapat dilakukan dengan menggunakan mikroorganisme resisten merkuri seperti bakteri resisten merkuri. Bila merkuri terpapar dalam tubuh manusia dengan kadar kecil dalam waktu yang sangat lama dapat membuat bakteri tersebut beradaptasi bahkan mampu mereduksi merkuri tersebut sehingga menjadi tidak berbahaya. Penelitian ini bertujuan untuk mengetahui apakah bakteri Bacillus resisten terhadap merkuri dan gentamisin. Penelitian uji resistensi merkuri pada Bacillus dilakukan menggunakan media LB cair yang telah diinkubasi selama 24 jam dan didapatkan pada pengenceran 10 ppm, 20 ppm, dan 40 ppm ada koloni bakter atau resisten tetapi pada pengenceran 80 ppm tidak ada pertumbuhan koloni bakteri. Pada uji resistensi terhadap gentamisin menggunakan media LB padat yang telah diinkubasi selama 24 jam didapatkan hasil zona hambat gentamisin $15 \mathrm{~mm}$. Simpulan: Bacillus resisten terhadap merkuri sampai dengan pengeceran 40 ppm tetapi tidak resisten pada merkuri pengenceran $80 \mathrm{ppm}$ dan gentamisin.
\end{abstract}

Kata kunci: bacillus, merkuri, gentamisin, resisten

Merkuri adalah unsur logam yang sangat penting dalam teknologi di abad modern ini. Merkuri adalah unsur yang mempunyai nomor atom $(\mathrm{NA}=80)$ serta mempunyai massa molekul relatif $(\mathrm{MR}=200,59)$.
Merkuri diberikan simbol kimia Hg yang merupakan singkatan yang berasal bahasa Yunani Hydrargyricum, yang berarti cairan perak. Bentuk fisik dan kimianya sangat menguntungkan karena merupakan satu- 
satunya logam yang berbentuk cair dalam temperatur kamar $\left(25^{\circ} \mathrm{C}\right)$ titik bekunya paling rendah $\left(-39^{\circ} \mathrm{C}\right)$, mempunyai kecenderungan menguap lebih besar, mudah bercampur dengan logam logam lain menjadi logam campuran (amalgam/Alloi), juga dapat mengalirkan arus listrik sebagai konduktor baik tegangan arus listrik tinggi maupun tegangan arus listrik rendah. ${ }^{1}$

Orang-orang yang secara teratur terkena (paparan kronis) merkuri yang tinggi (seperti populasi yang mengandalkan pekerjaan memancing atau orang-orang yang pekerjaannya terekspos). Di antara memancing, antara 1,5/1000 dan 17/1000 anak-anak menunjukkan kerusakan kognitif (retardasi mental ringan) yang disebabkan oleh konsumsi ikan yang mengandung merkuri.Populasi ini termasuk di Brazil, Kanada, Cina, Columbia dan Greenland. ${ }^{2}$

Merkuri juga dipakai untuk pembuatan amalgam. Dimana amalgam merupakan campuran logam, yang diantaranya adalah merkuri sudah digunakan sejak 150 tahun yang lalu oleh kedokteran gigi sebagai penambal gigi berlubang dan sampai sekarang amalgam masih digunakan oleh dokter gigi karena merupakan bahan tambalan yang kuat dan tahan lama. Namun resiko utama amalgam adalah pelepasan uap merkuri yang mungkin terjadi selama penggunaannya di rongga mulut. Penggunaan amalgam ini memicu munculnya bakteri resisten terhadap merkuri dimana bakteri mampu untuk mereduksi ion $\mathrm{Hg}^{2+}$ menjadi $\mathrm{Hg}^{0}$ oleh enzim merkuri reduktase, yang sebelumnya bersifat toksik menjadi kurang toksik, termasuk bakteri bacillus. ${ }^{3}$

Keberhasilan klinis pada saat ini merupakan gambaran untuk mengetahui etiologi dari infeksi gigi (odontogen), seleksi yang tepat dari pemberian variasi antimikrobial dalam mencegah dan merawat infeksi gigi, pengaturan akibat yang terjadi ketika dihubungkan dengan prosedur pengobatan gigi, serta kemampuan resistensi bakteri terhadap bahan tertentu. ${ }^{4}$ Penelitian ini betujuan untuk menguji resistensi bakteri Bacillus yang di isolasi dari plak gigi terhadap merkuri dan antibiotik gentamisin.

\section{METODE PENELITIAN}

Desain penelitian yang digunakan ialah metode deskriptif eksploratif. Sampel penelitian ialah bakteri Bacillus yang tumbuh pada media Luria Bertani (LB) broth. Penelitian berlangsung pada bulan November - Desember 2014. Penelitian ini dimulai dengan persiapan alat dan bahan, pengambilan sampel di Laboritorium Mikrobiologi FMIPA Unsrat, pemeriksaan sampel, kemudian dilakukan uji resistensi merkuri dan uji resistensi antibiotik.

\section{HASIL PENELITIAN}

\section{Hasil Isolasi Bakteri Resistensi Merkuri}

Dari hasil pengamatan setelah diinkubasi pada suhu $37^{\circ} \mathrm{C}$ selama 24 jam pada $\mathrm{HgCl}_{2}$ dengan pengeceran yang ada, didapatkan bakteri isolat yang diidentifikasi dari plak gigi dengan hasil pertumbuhan banyak pada konsentrasi 10 ppm, pertumbuhan sedang pada konsentrasi 20 ppm, dan pertumbuhan sedikit pada konsentrasi 40 ppm. Kemudian diambil isolat bakteri yang pertumbuhannya terbanyak (konsentrasi 10 ppm) dan dilakukan pemeriksaan identifikasi bakteri dan uji resistensi antibiotik gentamisin.

Tabel 1. Hasil Isolasi Bakteri Resistensi Merkuri

\begin{tabular}{lcc}
$\begin{array}{l}\text { Media } \begin{array}{l}\text { Luria } \\
\text { Bertani } \\
\text { Broth }\end{array} \\
\text { (LB) }\end{array}$ & Pertumbuhan & Keterangan \\
\hline $10 \rho \rho \mathrm{m}$ & + & $\begin{array}{l}\text { Pertumbuhan } \\
\text { banyak } \\
20 \rho \rho \mathrm{m}\end{array}$ \\
& + & $\begin{array}{c}\text { Pertumbuhan } \\
\text { sedang }\end{array}$ \\
$40 \rho \rho \mathrm{m}$ & + & $\begin{array}{c}\text { Pertumbuhan } \\
\text { sedikit }\end{array}$ \\
$80 \rho \rho \mathrm{m}$ & & Tidak ada \\
\hline
\end{tabular}

\section{Hasil Uji Resisten Antibiotik Gentamisin}

Bakteri yang telah didapatkan dari uji resistensi merkuri yaitu Bacillus kemudian dilakukan uji terhadap resistensi antibiotik yaitu gentamisin dengan pengulangan pemberian antibiotik gentamisin sebanyak 
tiga kali pengulangan.

Dari hasil pengamatan yang telah dilakukan di Laboratorium Mikrobiologi Farmasi, Program Studi Farmasi, Fakultas MIPA Universitas Sam Ratulangi, setelah bakteri Bacillus diinkubasi selama 24 jam dalam antibiotik didapatkan bahwa pada pengulangan pemberian antibiotik Bacillus yang ada didalam cakram didapatkan hasil bahwa pada pemberian yang pertama diameter zona hambat Bacillus terhadap antibiotik gentamisin sebesar $15 \mathrm{~mm}$ $(\geq 12 \mathrm{~mm})$ dan termasuk dalam kategori sensitif, dan pada pengulangan pemberian antibiotik gentamisin kedua dan ketiga didapatkan hasil yang sama.

\begin{tabular}{ccc}
\hline $\begin{array}{c}\text { Pengulangan } \\
\text { Pemberian } \\
\text { Antibiotik } \\
\text { Gentamisin }\end{array}$ & $\begin{array}{c}\text { Zona } \\
\text { Hambat }\end{array}$ & Keterangan \\
\hline I & $15 \mathrm{~mm}$ & \\
II & $15 \mathrm{~mm}$ & Sensitif $(\geq 12 \mathrm{~mm})$ \\
III & $15 \mathrm{~mm}$ & Sensitif $(\geq 12 \mathrm{~mm})$ \\
\hline
\end{tabular}

\section{BAHASAN}

Bakteri adalah suatu organisme yang jumlahnya paling banyak dan tersebar luas di bandingkan dengan organisme lainnya di bumi, dimana bakteri memiliki jumlah spesies mencapai ratusan ribu bahkan lebih. Bakteri adalah prokariot, uniseluler yang hanya diamati dengan menggunakan mikroskop. Bakteri hidup secara sendirisendiri (soliter) atau berkelompok (koloni). ${ }^{5}$

Berdasarkan hasil peneltian yang dilakukan dengan mengambil sampel plak gigi pasien dengan tumpalan amalgam, maka ditemukan adanya bakteri resistensi merkuri pada sampel tersebut dimana hasil uji resistensi merkuri menunjukan semua isolat tumbuh pada pemberian $\mathrm{HgCl}_{2}$ dan diinkubasi selama 48 jam.

Kemampuan reduksi setiap kultur bakteri yang diperoleh terhadap merkuri adalah berbeda. Perbedaan resistensi ini berhubungan dengan mekanisme respon populasi bakteri terhadap merkuri dengan metabolism sel melalui sistem operon resistensi dalam plasmid untuk menginduksi reduksi merkuri. ${ }^{6}$

Selain itu suhu dan $\mathrm{pH}$ merupakan faktor lingkungan yang sangat menetukan kehidupan bakteri. Suhu yang rendah dapat menyebabakan aktifitas enzim menurun dan jika suhu terlalu tinggi dapat mendenaturasi protein enzim. Pada suhu optimum pertumbuhan bakteri berlangsung dengan cepat. Diluar kisaran suhu optimum pertumbuhan bakteri menjadi lambat atau tidak ada pertumbuhan. ${ }^{7}$

Uji resistensi merkuri ini dilakukan pada media LB broth dengan menggunakan metode gores. Kemudian menumbuhkan bakteri Bacillus tersebut kedalam media LB brot dengan menggunakan konsentrasi merkuri $\left(\mathrm{HgCl}_{2}\right)$ yang berbeda-beda yaitu 10ppm, 20ppm, 40ppm dan 80ppm. Uji resistensi merkuri ini bertujuan untuk melihat konsentrasi kemampuan bakteri dapat tumbuh.

Dari hasil uji resisten merkuri $\left(\mathrm{HgCl}_{2}\right)$ terhadap Bacillus menunjukkan bahwa bakteri ini sangat berpengaruh nyata terhadap tingginya konsentrasi merkuri $\left(\mathrm{HgCl}_{2}\right)$ dapat dilihat pada Tabel 1 .

Berdasarkan Tabel 1, hasil menunjukkan pada merkuri $\left(\mathrm{HgCl}_{2}\right)$ konsentrasi 10 ppm terjadi pertumbuhan lebih cepat dari pada merkuri $\left(\mathrm{HgCl}_{2}\right)$ konsentrasi 20 ppm, dan merkuri $\left(\mathrm{HgCl}_{2}\right)$ konstrasi 20 ppm pertumbuhannya lebih cepat dari pada merkuri $\left(\mathrm{HgCl}_{2}\right)$ konsentrasi 40 ppm. Sedangkan merkuri $\left(\mathrm{HgCl}_{2}\right)$ konsentrasi 80 ppm sudah tidak ada lagi pertumbuhan bakteri. Pada merkuri $\left(\mathrm{HgCl}_{2}\right)$ konsentrasi $40 \mathrm{ppm}$ yang tumbuh pada media LB broth diduga; pertama, bakteri resistensi terhadap merkuri dengan tingkat ketahanan merkuri yang cukup tinggi. Kedua, adanya plasmid yang mengandung gen resisten merkuri yang masuk ke dalam sel.

perbedaan resistensi ini sehubungan dengan mekanisme respon populasi bakteri terhadap merkuri. Ada tiga mekanisme respon terhadap stres merkuri. Pertama, dengan cara menghambat metabolisme sel sehingga pertumbuhan sel lambat atau mati. Kedua, menginduksi sistem operon resisten merkuri untuk bekerja sehingga sel 
tetap dalam kondisi tres. Ketiga, adanya plasmid yang mengandung gen resistensi merkuri yang masuk ke dalam sel. ${ }^{8}$

Kultur bakteri Bacillus pada merkuri konsentrasi 40 ppm dan 80 ppm menunjukkan resistensi merkuri lebih rendah dibandingkan dengan merkuri konsentrasi 10 ppm dan 20 ppm. Kemungkinan bakteri Bacillus pada merkuri konsentrai 40 ppm dan 80 ppm memiliki respon dengan cara pertama yaitu menghambat metabolisme sel sehingga terjadi pertumbuhan yang lambat atau mati. Bakteri Bacillus yang memiliki merkuri konsentrasi 10 ppm, 20 ppm dan 40 ppm diduga mengandung gen resisten merkuri spektrum sempit dimana mer penentu resisten hanya terjadi pada garam merkuri organik saja berbeda dengan mer penentu resisten spektrum luas yang resisten terhadap metil merkuri dan fenil merkuri, serta garam merkuri anorganik. ${ }^{9}$

Setelah dilakukan uji resistensi bakteri terhadap merkuri, tahap selanjutnya yang dilakukan adalah uji resistensi bakteri terhadap antibiotik gentamisin.

\section{Uji Resistensi Antibiotik Gentamisin}

Antibiotika adalah zat-zat kimia oleh yang dihasilkan oleh fungi dan bakteri, yang memiliki khasiat mematikan ataumenghambat pertumbuhan kuman, sedangkan toksisitasnya bagi manusia relatif kecil. Turunan zat-zat ini, yang dibuat secara semi-sintesis, juga termasuk kelompok ini, begitu pula senyawa sintesis dengan khasiat antibakteri. ${ }^{8}$

Antibiotik adalah zat biokimia yang diproduksi oleh mikroorganisme, yang dalam jumlah kecik dapat menghambat pertumbuhan atau membunuh pertumbuhan mikroorganisme lain. ${ }^{9}$

Gentamisin merupakan salah satu jenis aminoglikosida, di antaranya amiksani, gentamisin, kanamisin, neomisin, netilmisin, paromomisin, tobramisin, dan ampramisin. Aminoglikosida yang berasal dari derivat genus Streptomyces diberi nama dengan akhiran mycin, sedangkan yang berasal dari derivat Micromonospora diberi nama dengan akhiran micin. ${ }^{10}$
Prinsip dari percobaan ini adalah penghambatan terhadap pertumbuhan mikroorganisme, yaitu zona hambatan akan terlihat sebagai daerah jernih di sekitar daerah yang mengandung zat antibakteri. Diameter zona hambatan pertumbuhan bakteri menunjukkan sensitivitas bakteri terhadap zat antibakteri. Selanjutnya dikatakan bahwa semakin lebar diameter zona hambatan yang terbentuk bakteri tersebut semakin sensitif.

Pada percobaan ini medium yang digunakan adalah medium NA (Nutrien Agar), karena medium ini dispesifikasikan untuk pembiakan bakteri Escherichia coli.

Berdasarkan hasil pengamatan setelah sampel diinkubasi selama 48 jam, diperoleh hasil bahwa pada cakram yang diberikan antibiotik gentamisin, terdapat zona hambat yang ditandai dengan daerah sekitar antibiotik berwarna bening. Diameter zona hambat antibiotik gentamisin adalah $15 \mathrm{~mm}$ $(\geq 12 \mathrm{~mm}$ ) dan termasuk kategori sensitif.

Gentamisin bekerja dengan cara berikatan dengan subunit 30S Ribosom bakteri (beberapa berikatan dengan subunit 50S), menghambat translokasi peptidiltRNA dari A-site ke P-site dan juga mengacaukan kode mRNA, sehingga menyebabkan bakteri gagal mensintesis protein vital untuk pertumbuhannya. ${ }^{10}$ bila tidak terjadi struktur urin oleh bakteri maka sensitifitasnya tidak akan berkurang. Urin merupakan tempat masuknya antibiotik agar antibiotik dapat bekerja pada dinding sitenya. Struktur purin yang tetap pada dinding sel bakteri menyebabkan bakteri masih sensitif terhadap antibiotik gentamisin.

\section{SIMPULAN}

Dari hasil penelitian yang dilakukan di Laboratorium Mikrobiologi FMIPA UNSRAT yang meliputi Uji Resistensi Merkuri $\mathrm{HgCl}_{2}$ dan Uji Resistensi Antibiotik Gentamisin dengan bakteri yang diuji Bacillus dapat bahwa bakteri Bacillus resisten terhadap merkuri sampai dengan pengeceran 40 ppm tetapi tidak resisten pada pengenceran $80 \mathrm{ppm}$. Uji resistensi antibiotik gentamisin menunjukkan hasil 
sensitif (tidak resisten).

\section{SARAN}

1. Perlu dilakukan penelitian lebih lanjut mengenai bakteri resisten merkuri tidak hanya satu bakteri saja teteapi lebih dari itu sehingga bisa mengetahui lebih banyak lagi bakteri yang telah resisten terhadap merkuri.

2. Perlu tindakan pencegahan atau detoksifikasi terhadap pengaruh merkuri yang cukup berbahaya, karena kemungkinan besar banyak masyarakat yang telah terpapar oleh merkuri

3. Perlu penelitian yang berlanjut untuk mencari antibiotik yang sensitif terhadap bacillus karena bakteri akan semakin resisten dengan antibiotik gentamisin

\section{UCAPAN TERIMA KASIH}

Ucapan terima kasih disampaikan kepada Widdhi Bodhi, SSi, MKes, Apt, Dr. dr. Billy J. Kepel, MMedSc, serta semua pihak, baik secara langsung maupun tidak langsung, yang telah memberikan ide dan gagasan kepada penulis.

\section{DAFTAR PUSTAKA}

1. Alfian Z. Merkuri; Antara Manfaat dan efek Penggunaannya bagi Kesehatan Manusia \& Lingkungan. Medan: Universitas Sumatera Utara; 2006.

2. WHO. Mercury and Health. 2013. Diakses melalui:

http://www.who.int/mediacentre/facts heets/fs361/en/

3. UNEP. Scientific Facts on Mercury.
Produced in 2002. Okt,2013. Diakses melalui:

http://www.greenfacts.org/en/mercur y/mercury-greenfacts-level2.pdf

4. Fatimawali, Badaruddin F, Yusuf $I$. Isolasi dan indentifikasi bakteri resisten merkuri dari muara sungai Sario yang dapat digunakan untuk detoksifikasi limbah merkuri. Oktober 2013. Diakses melalui: http://sulutiptek.com/documents/ident ifikasibakteriresistenmerkuridisungais ario.pdf

5. Jawet, Melnick, Adelberg. Mikrobiologi Kedokteran (23rd ed). Jakarta: EGC; 2007: p.251-8.

6. Fatimawali, Fatmawati B, Irawan $Y$. Isolasi dan Identifikasi Bakteri Resistensi Merkuri Dari Muara Sungai Sario yang dapat digunakan untuk detoksifikasi limbah Merkuri. Jurnal Ilmiah Sains. 2011;11(2).

7. Immanudin $\mathbf{H}$. Pola Pertumbuhan dan Toksisitas Bakteri Resistensi $\mathrm{HgCl}_{2}$. Jurnal EKOSAINS. 2010;2(1).

8. Smit E, Wolters A, Elsas JDV. SelfTransmissible Mercury Resistance Plamids with Gene Mobilizing Capacity in Soil Bacterial Populations: Influence of Wheat Roots And Mercury Addition. Appl. Environ. Microbiol. 1998;64:1210-9.

9. Misra TK. Bacterial Resistances to Inorganic Mercury Salt and Organomercurial. Plasmid . 1992;25: 4.

10. Tjay TH, Rahardja K. Obat-Obat Penting Khasiat, Penggunaan, dan Efek-Efek Sampingnya (6th ed). Jakarta, PT Elex Media Komputindo, 2007; p.193. 